\title{
Pengetahuan dan Perilaku Sadari Berbasis Aplikasi Untuk Deteksi Dini Tumor Payudara pada Wanita Usia Subur
}

\author{
*Nur alam ${ }^{1)}$, Suryani Soepardan ${ }^{2)}$, Firman F Wirakusumah ${ }^{3)}$ \\ ${ }^{1)}$ Fakultas Kesehatan, Universitas Mohammad Husni Thamrin, Jakarta \\ ${ }^{2)}$ Fakultas Kedokteran, Universitas Padjadjaran, Bandung \\ ${ }^{3)}$ Program studi S2 Terapan Kebidanan, STIKES Dharma Husada, Bandung
}

Corresponden author: snuralamsst1390@gmail.com

Received : 19 Januari $2021 \quad$ Accepted : 29 Maret 2021

Published: 30 Maret 2021

DOI: https://doi.org/10.37012/jik.v13i1.441

\begin{abstract}
ABSTRAK
Kanker payudara adalah salah satu kanker paling banyak di dunia yang sering muncul dan sangat menakutkan bagi perempuan. Data Yayasan Kanker Payudara Indonesia (YKPI) menemukan, dari 2.515 perempuan yang memeriksakan payudara mereka lewat mammografi, $1,2 \%$ diantaranya dicurigai tumor ganas dan 14,8\% diantaranya dicurigai jinak. Tujuan penelitian ini adalah untuk Menganalisis pengetahuan dan Perilaku SADARI Berbasis Aplikasi Untuk Deteksi Dini Tumor Payudara Pada Wanita Usia Subur. Metode dalam penelitian ini adalah Quasi Eksperimental dengan teknik pretest-posttest two group design adapaun jumlah sampelnya 64 WUS dibagi dalam dua kelompok. Waktu dilaksanakan pada bulan MeiJuni 2018. Pengambilan sampel yaitu consecutive sampling. Hasil analisis data tingkat pengetahuan sesudah diberikan perlakuan yaitu meningkat sebesar 50,75\% (dari 11,88 menjadi 17,91) dengan nilai signfikan sebesar 0,003 sedangkan perilaku sesudah diberikan perlakuan yaitu meningkat sebesar $85,71 \%$ (dari 7 Wanita usia subur menjadi 13 wanita usia subur yang berperilaku baik) dengan nilai signifikan 0,000. Sehingga dapat disimpulkan bahwa ada pengaruh penggunaan aplikasi deteksi dini tumor payudara terhadap peningkatan pengetahuan dan dapat merubah perilaku wanita usia subur dalam melakukan SADARI. Rekomendasi perlunya dilakukan penelitian lebih lanjut mengenai aplikasi deteksi dini tumor payudara untuk memperbaiki pengetahuan dan perilaku WUS dalam melakukan SADARI.
\end{abstract}

Kata Kunci: Aplikasi Deteksi Dini Tumor Payudara, Pengetahuan, dan Perilaku.

\section{ABSTRACT}

Breast cancer is one of the most common cancers in the world that often attacks and is very frightening for women. Data from the Indonesian Breast Cancer Foundation (YKPI) found, from 2,515 women who examined their breasts through mammography, $1.2 \%$ of them suspected of malignant tumors and $14.8 \%$ were suspected of being benign.. The purpose of this study was to analyze the knowledge and behavior of $B S E$ based on applications for early detection of breast tumors in fertile women. The research method used was Quasi Experimental with a pretest-posttest two group approach with a total sample of 64 WUS divided into two groups. The study was conducted in May-June 2018. Sampling was done using consecutive sampling. The independent variable in this study is the use of Breast Tumor Early Detection applications and leaflets, while the dependent variable is knowledge and behavior. Result, The research result showed that there was an influence in the knowledge levels between pretest and posttest group after intervention using Early Detection Breast Cancer Application which was about 50.75\% ( $p=0.003)$, and there was a behavioural change for mothers who had done SADARI which was about $85,71 \%$. ( $p=0.000$ ). So it can be concluded that Early Detection Breast Cancer Application has an influence in improving knowledge, and a behavior change for women in fertile age to do SADARI.

Key word: Application Breast Tumor Early Detection, Knowledge, and Behavior. 


\section{PENDAHULUAN}

Kanker payudara menjadi salah satu kanker paling umum di dunia yang sering menyerang dan sangat menakutkan bagi perempuan. Tingkat Incidence Rate (IR) bervariasi hampir empat kali lipat di seluruh dunia, mulai dari 27 kasus per 100.000 di Afrika Tengah dan Asia Timur sampai 92 kasus per 100.000 di Amerika Utara. Data Yayasan Kanker Payudara Indonesia (YKPI) menemukan, dari 2.515 perempuan yang memeriksakan payudara mereka lewat mammografi, 1,2\% diantaranya dicurigai tumor ganas dan 14,8\% diantaranya dicurigai jinak, sedangkan hingga Desember 2017 dari 3.160 perempuan yang diperiksa 1,4\% diantaranya dicurigai tumor ganas. Adapun data dari dinas kesehatan kota Bandung, kasus baru yang didapatkan setelah dilakukan skrining kanker payudara sebanyak 174 orang dan yang menderita kanker payudara sebanyak 186 orang sedangkan yang meninggal karena kanker payudara sebanyak 22 orang, selain itu data dari puskesmas Ibrahim Adji, setelah dilakukan skrining kanker payudara didapatkan 2 orang yang terdapat benjolan dan yang dicurigai kanker payudara sebanyak 4 orang. Besarnya permasalah kanker di Indonesia yaitu kebanyakan datang sudah dalam keadaan yang cukup parah yaitu $60-70 \%$ penderita stadium III-IV (stadium lanjut). Hal yang paling penting dilakukan adalah dengan adanya peningkatan upaya promotif dan preventif dalam penanggulangan kanker payudara. Semakin berkembangnya teknologi di zaman era informatika seperti sekarang ini, informasi tentang payudara bukanlah sesuatu yang sulit didapatkan, dalam hal ini diperlukan sebuah sistem informasi yang mudah dan praktis dapat dibuka setiap saat. Penggunaan teknologi informasi untuk bidang kesehatan (e-health dan m-health) di Indonesia telah diatur dalam UU No. 36 tahun 2009 tentang kesehatan, dalam hal ini untuk menyelenggarakan upaya kesehatan yang efektif dan efisien diperlukan informasi kesehatan yang dilakukan melalui sistem informasi untuk meningkatkan pengetahuan dan mendukung pembangunan kesehatan. Salah satu perkembangan teknologi yang dapat digunakan untuk memperoleh informasi yaitu penggunaan smartphone yang memiliki tambahan Aplikasi Personal Digital Assistant (PDA), 
internet akses, pesan singkat, penerima email dan lain-lain. Pada penelitian ini peneliti bersama dengan team membuat aplikasi berbasis android dan menamakan aplikasi kami dengan nama”Aplikasi Deteksi Dini Tumor Payudara”, aplikasi ini paling sederhana, mudah untuk dipelajari, dan dibuat lebih menarik karena dipadukan unsur-unsur multimedia yaitu dengan menggabungkan teks, gambar, suara, animasi dan video. Keunggulan dari aplikasi ini dibandingkan aplikasi lain adalah memiliki daftar kunjungan yang bisa digunakan oleh profesi kesehatan dalam memantau penggunaan aplikasi dalam melakukan SADARI. Aplikasi ini dapat di download pada smartphone berbasis android, yang digunakan sebagai panduan untuk memperoleh informasi mengenai kesehatan payudara yang di dalamnya memuat tentang anatomi payudara, klasifikasi tumor, audio visual SADARI, keluhan (evaluasi pemeriksaan), kalender SADARI, alarm (pengingat) SADARI, dan daftar kunjungan. Adanya aplikasi Deteksi Dini Tumor Payudara diharapkan dapat mengubah perilaku tidak sehat menjadi perilaku sehat yaitu pengetahuan yang dimiliki akan mengubah sikap dan akhirnya berubah menjadi tindakan yang dapat menjadi kebiasaan yang harus dipenuhi oleh wanita khususnya wanita usia subur untuk rutin melakukan pemeriksaan payudara sendiri (SADARI). Dalam literatur penelitian maupun praktik, perubahan perilaku menjadi tolak ukur pengaruh sistem informasi. Adapun tujuan dari penelitian ini adalah menganalisis pengaruh penggunaan Aplikasi Deteksi Dini Tumor Payudara terhadap peningkatan pengetahuan dan perubahan perilaku wanita usia subur (WUS) dalam melakukan SADARI.

\section{METODE}

Metode yang digunakan dalam penelitian ini adalah kuantitatif dengan rancangan kuasi eksperimen pada dua kelompok dengan teknik pretest and posttest control group design. Penelitian ini dilaksanakan wilayah kerja Puskesmas Ibrahim Adji Kota Bandung pada bulan Mei-Juni 2018. Populasi dalam penelitian ini Wanita Usia Subur di wilayah kerja Puskesmas Ibrahim Adji Kota Bandung yang ada selama penelitian berlangsung, jumlah sampel pada setiap kelompok adalah 32 orang. Sampel dipilih 32 untuk kelompok aplikasi Deteksi Dini 
Tumor Payudara dan 32 untuk kelompok leaflet. Total sampel 64 orang, dengan teknik consecutive sampling. Alasan utama peneliti memilih rancangan ini karena sesuai dengan tujuan penelitian untuk menilai pengaruh suatu tindakan atau perlakuan yang merupakan suatu intervensi baru terhadap suatu perilaku atau efek yang tidak akan diperoleh dari metode non-eksperimen. Instrumen yang digunakan dalam pengumpulan data adalah kuesioner dengan sejumlah pertanyaan tentang pengetahuan dan perilaku. Kuesioner ini terdiri atas karakteristik, pengetahuan, dan perilaku wanita usia subur dalam melakukan SADARI.

\section{HASIL DAN PEMBAHASAN}

Penelitian ini mengenai Pengaruh Penggunaan Aplikasi Deteksi Dini Tumor Payudara Terhadap Peningkatan Pengetahuan dan Perubahan Perilaku Wanita Usia Subur dalam Melakukan SADARI, sudah dilaksanakan di Puskesmas Ibrahim Adji dari bulan juni 2018 sampai dengan juli 2018 sebanyak 64 sampel.

\section{Analisis Univariat}

Tabel 1.

Distribusi Frekuensi Karakteristik Subjek Penelitian berdasarkan Umur, Pendidikan dan Pekerjaan

\begin{tabular}{clccccc}
\hline \multirow{2}{*}{ Karakteristik } & \multirow{2}{*}{ Kategori } & \multicolumn{5}{c}{ Kelompok } \\
\cline { 3 - 6 } & & \multicolumn{2}{c}{ Aplikasi } & \multicolumn{2}{c}{ Leaflet } & \multirow{2}{*}{ Nilai p } \\
\cline { 3 - 6 } & & $\mathbf{n}$ & $\mathbf{\%}$ & $\mathbf{n}$ & $\mathbf{\%}$ & \\
\hline \multirow{2}{*}{ Umur } & 20-34 tahun & 17 & 53.1 & 24 & 75.0 & \multirow{2}{*}{0,118} \\
& $35-49$ tahun & 15 & 46.9 & 8 & 25.0 & \\
\hline \multirow{2}{*}{ Pendidikan } & Rendah & 22 & 68.8 & 23 & 71.9 & \multirow{2}{*}{1,000} \\
& Tinggi & 10 & 31.2 & 9 & 28.1 & \\
\hline \multirow{2}{*}{ Pekerjaan } & Tidak & 21 & 65.6 & 13 & 40.6 & \multirow{2}{*}{0,080} \\
& Bekerja & 11 & 34.4 & 19 & 59.4 & \\
& Bekerja & 11 & & &
\end{tabular}

Dari tabel di atas, diketahui bahwa karakteristik umur pada kelompok intervensi dengan menggunakan Aplikasi sebanyak 17 WUS (53,1\%) berumur 20-34 tahun, sedangkan kelompok kontrol sebanyak 24 WUS (75.0\%) berumur 20-34 tahun. Karakteristik pendidikan Pada kelompok Intervensi, sebanyak 22 WUS (68.8\%) berpendidikan rendah, sedangkan pada kelompok kontrol sebanyak 23 WUS (71.9\%) yang berpendidikan rendah. Karakteristik pekerjaan pada kelompok intervensi sebanyak 21 WUS (65.6\%) yang tidak bekerja, sedangkan pada kelompok kontrol sebanya2 13 WUS (40.6\%) yang tidak bekerja. 


\section{Analisis Bivariat}

Tabel 2.

Pengaruh Penggunaan Aplikasi Deteksi Dini Tumor Payudara Terhadap Peningkatan Pengetahuan

\begin{tabular}{ccccc}
\hline \multirow{2}{*}{ Kelompok } & \multicolumn{2}{c}{ Skor Pengetahuan } & Peningkatan & Nilai p \\
\cline { 2 - 3 } & Pre & Post & $(\boldsymbol{\%})$ & \\
\hline Aplikasi & 11,88 & 17,91 & 50,76 & 0,003 \\
Leaflet & 12,0 & 12,81 & 6,75 & 0,317 \\
\hline
\end{tabular}

Tabel di atas menunjukkan hasil bahwa pengetahuan pada kelompok yang menggunakan aplikasi deteksi dini tumor payudara meningkat sebesar 50,76\% (dari 11,88 menjadi 17,91) setelah menggunakan aplikasi smartphone, sedangkan pada kelompok kontrol peningkatan pengetahuan hanya sebesar $6,75 \%$ (dari 12,0 menjadi 12,81) Dengan selilih peningkatan antara intervesi dan kontrol adalah 44,01\%( $\Delta)$. Hasil analisis data menggunakan uji Wilcoxon menunjukkan bahwa pada kelompok intervensi, ada perbedaan pengetahuan antara sebelum dan setelah intervensi $(\mathrm{p}=0,003)$. Dengan demikian berarti, penggunaan Aplikasi deteksi dini tumor payudara yang diberikan pada kelompok intervensi dapat meningkatkan pengetahuan ibu.

Tabel 3.

Pengaruh penggunaan Aplikasi Deteksi Dini Tumor Payudara Terhadap Perubahan Perilaku.

\begin{tabular}{|c|c|c|c|c|}
\hline \multirow[t]{2}{*}{ Kelompok } & \multicolumn{2}{|c|}{$\begin{array}{c}\text { Rata-rata } \\
\text { (min-maks) Skor Perilaku }\end{array}$} & \multirow{2}{*}{$\begin{array}{c}\text { Peningkatan } \\
\text { Perilaku Baik } \\
(\%)\end{array}$} & \multirow[t]{2}{*}{ Nilai $p$} \\
\hline & Pre & Post & & \\
\hline Aplikasi & $\begin{array}{c}58,19 \\
(38,0-85,0) \\
\end{array}$ & $\begin{array}{c}65,66 \\
(49.0-85,0) \\
\end{array}$ & 85,71 & 0,001 \\
\hline Leaflet & $\begin{array}{c}59,94 \\
(39.0-83.0)\end{array}$ & $\begin{array}{c}61,66 \\
(40,0-83,0)\end{array}$ & 14,29 & 0,306 \\
\hline
\end{tabular}

Tabel di atas menunjukkan hasil bahwa rata-rata skor perilaku pada kelompok yang diberikan aplikasi deteksi dini kanker payudara meningkat sebesar 85,71\% (dari 7 WUS menjadi 13 WUS yang berperilaku baik) setelah menggunakan aplikasi smartphone, sedangkan pada kelompok kontrol peningkatan perilaku hanya sebesar 14,29\% (dari 7 orang menjadi 8 orang yang berperilaku baik), dengan selisih peningkatan antara intervesi dan kontrol adalah $71,42 \%(\Delta)$. Hasil analisis data menggunakan uji Wilcoxon menunjukkan bahwa, pada kelompok intervensi, ada perbedaan perilaku antara sebelum dan setelah intervensi $(\mathrm{p}=$ 0,001). Dengan demikian berarti, penggunaan Aplikasi deteksi dini tumor payudara yang diberikan pada kelompok intervensi dapat merubah perilaku WUS. 


\section{PEMBAHASAN}

\section{Pengaruh Penggunaan Aplikasi Deteksi Dini Tumor Payudara terhadap Peningkatan Pengetahuan Ibu dalam melakukan SADARI}

Hasil penelitian menunjukkan hasil bahwa pengetahuan pada kelompok yang menggunakan aplikasi smartphone Sadari meningkat sebesar 50,76\% (dari 11,88 menjadi 17,91) setelah menggunakan aplikasi smartphone, sedangkan pada kelompok kontrol peningkatan pengetahuan hanya sebesar 6,75\% (dari 12,0 menjadi 12,81), dengan selisih peningkatan antara intervensi dan kontrol adalah $44,01 \%(\Delta)$. Analisis data pengetahuan Post hasilnya bermakna dengan uji Wilcoxon $(\mathrm{p}=0,003)$. Dengan demikian berarti, penggunaan Aplikasi smartphone SADARI yang diberikan pada kelompok intervensi dapat meningkatkan pengetahuan ibu mengenai SADARI.

Hasil penelitian ini menunjukkan bahwa tingkat pengetahuan tentang pemeriksaan payudara sendiri pada kelompok intervensi lebih tinggi dibandingkan dengan kelompok kontrol. Hal ini berarti bahwa aplikasi memiliki intensitas yang cukup tinggi untuk mengartikan bahan pendidikan. Sementara itu, penyampaian materi yang hanya melalui kata-kata sangat kurang efektif, namun media akan lebih efektif jika berkolaborasi dengan alat peraga lainnya karena materi dan pesan kesehatan yang disampaikan lebih mudah sampai dan dipahami masyarakat yang menjadi peserta kegiatan promosi kesehatan. Idealnya, semakin banyak indera manusia yang digunakan untuk menerima sesuatu, akan semakin banyak dan jelas pula pemahaman yang didapat terhadap sesuatu tersebut, hal ini berdampak pada kemampuan daya ingat seseorang. ${ }^{25}$ Hal ini sejalan dengan penelitian yang dilakukan oleh Liu M, dkk mengungkap bahwa Pengetahuan yang meningkat tentang perawatan payudara sendiri (SADARI) menyebabkan perilaku yang bertanggung jawab dalam perawatan payudaranya.

Sejalan dengan penelitian yang dilakukan oleh Ferdiani dan Azam mengungkap bahwa Pemberian materi kanker payudara dan deteksi dini dengan SADARI melalui media efektif dalam meningkatkan pengetahuan, dimana nilai sebelum diberi materi rata-rata 47,37\% dan setelah diberi materi melalui media sosial mengalami peningkatan yaitu 77,77\%. Sedangkan hasil dari penelitian yang telah dilakukan Masih terdapat pengetahuan responden yang kurang setelah diberikan penyuluhan dikarenakan kurangnya perhatian responden saat diberikan penyuluhan dengan menggunakan aplikasi. Hal ini sesuai dengan teori yang menjelaskan bahwa faktor yang mempengaruhi pengetahuan salah satunya adalah penambahan informasi melalui media smartphone yang dapat dengan mudah diterima oleh responden. Keuntungan penggunaan smartphone dibandingkan dengan media lain diantaranya adalah smartphone 
mudah dibawa, mudah digunakan, dapat digunakan kapan saja dan petugas kesehatan dapat lebih efisien dalam melakukan tugasnya, lebih menarik dan mengikutsertakan seluruh panca nidera.

\section{Pengaruh Penggunaan Aplikasi Deteksi Dini Tumor Payudara terhadap Perubahan Perilaku Ibu dalam melakukan SADARI}

Berdasarkan hasil penelitian pada tabel 3 menunjukkan hasil bahwa rata-rata skor perilaku pada kelompok yang diberikan aplikasi deteksi dini tumor payudara meningkat sebesar 85,71\% (dari 7 WUS menjadi 13 WUS yang berperilaku baik) setelah menggunakan aplikasi smartphone, sedangkan pada kelompok kontrol peningkatan perilaku hanya sebesar $14,29 \%$ (dari 7 orang menjadi 8 orang yang berperilaku baik), dengan selisih peningkatan antara intervesi dan kontrol adalah 71,42\% ( $\Delta$ ). Hasil analisis data menggunakan uji Wilcoxon menunjukkan bahwa, pada kelompok intervensi, ada perbedaan perilaku antara sebelum dan setelah intervensi $(\mathrm{p}=0,001)$. Dengan demikian berarti, penggunaan Aplikasi deteksi dini tumor payudara yang diberikan pada kelompok intervensi dapat merubah perilaku WUS.

Hasil penelitian yang dilakukan oleh Heo J mengungkap bahwa setelah menggunakan aplikasi jumlah peserta yang berlatih melakukan pemeriksaan payudara sendiri (BSE) meningkat (62.2\% ke 71.1\%), dan jumlah mereka yang menggunakannya pada waktu yang tepat naik dari 1 sampai 15 (2.2\% menjadi 33.3\%), sehingga disimpulkan bahwa penggunaan aplikasi smartphone efektif dalam meningkatkan praktik pemeriksaan payudara sendiri ( SADARI) pada wanita usia subur.

Android merupakan suatu sistem operasi berbasis linux yang bisa digunakan untuk telepon seluler (mobile) dalam hal ini telepon pintar (smartphone) dan komputer tablet (PDA). Android menyiapkan platform terbuka untuk para pengembang dalam menciptakan aplikasi mereka sendiri yang digunakan oleh bermacam peranti bergerak. Android sekarang telah menjadi sistem operasi mobile yang populer di dunia.

\section{SIMPULAN DAN REKOMENDASI}

Melihat hasil dari penelitian yang telah dilakukan dapat disimpulkan bahwa ada pengaruh penggunaan aplikasi deteksi dini tumor payudara terhadap peningkatan pengetahuan dan dapat merubah perilaku wanita usia subur dalam melakukan SADARI. Adapun rekomendasi dari penelitian ini yaitu perlu dilakukan penelitian lebih lanjut mengenai aplikasi deteksi dini tumor payudara untuk memperbaiki pengetahuan dan perilaku WUS dalam melakukan 
SADARI selain itu penelitian dapat dijadikan sebagai salah satu sumber informasi dalam melakukan promosi kesehatan menggunakan aplikasi deteksi dini tumor payudara.

\section{REFERENSI}

1. Naviri tim. Buku pintar kesehatan dan kecantikan payudara. Jakarta: elex media komputindo; 2016.

2. KEMENKES. Buletin Kanker. Pusat Data dan Informasi Kementerian Kesehatan RI; 2016.

3. Peraturan Menteri Kesehatan Republik Indonesia Nomor 34 tahun 2015 tentang Penanggulangan Kanker Payudara dan Kanker Leher Rahim; 2015.

4. YKPI. Cara mendeteksi kanker payudara sejak dini. Webpro Indonesia: 2013-2017. Tersedia dari: https://www.pitapink-ykpi.or.id (di unduh 02 feb 2018).

5. Dinas kesehatan Kota bandung. Data penyakit tidak menular 2017. Bandung: dinas kesehatan kota bandung; 2017.

6. Hassan EE, Seedhom AE, Mahfouz EM. Awareness about breast cancer and its screening among rural egyption women, minia district: a population-based study. 2017;18(6):1623-8.

7. Pengpid S, Peltzer K. Knowledge, attitude, and practice of breast self-examination among female university students from 24 low, middle income and emerging economy countries. Asian Pac J Cancer Prev. 2014;15(20):8637-40.

8. Induniasih dan Ratna W. Promosi kesehatan. Yogyakarta: Pustaka Baru Press; 2017.

9. Olfah Y,dkk. Kanker payudara dan sadari. Jakarta: Nuha Medika ; 2013.

10. Suparyanto. Wanita usia subur. Tersedia dari: https: //www. scribd. com/ document/ 356140969/ dr-wus/ 12/08/2017 (diunduh 02 februari 2018).

11. Permenkes. Undang-undang No. 36 Tahun 2009 tentang Kesehatan; 2009.

12. Ferdiani DA, Azam M. Media sosial facebook sebagai sarana pemberian materi kanker payudara. J of Health educ. 2016;1(2):8-14.

13. Fitri FE. Penaerapan teknologi informasi mobile health (mhealth) dalam peningkatan pelayanan kesehatan pada ibu hamil. Jakarta: pasca sarjana kekhususan keperawatan maternitas FIK UI ; 2016. Tersedia dari : https: //www. kompasiana. com/ fenieldafitri/penerapan-teknologi-informasi-mobile-helath-mhealth-dalampeningkatan-pelayanan-kesehatan-pada-ibu-hamil(diunduh 01 februari 2018). 
14. Hall CM. Bierman KL. Technology-assisted interventions for parent of young children: emerging practices, current research, and future directions. Early Child Res Q. 2015;33:21-42.

15. Valk J-H, Rasyid AT, Elder L. Using mobile phone to improve educational outcomes: an analysis of evidence from Asia. Int Rev Res Learn.2010;11(1):117-40.

16. Otu A, Ebenso B, Okuzu O, Osifo-Dawodu E. Using a mHealth tutorial application to change knowledge and attitude of frontline health workers to Ebola Virus disesase in Nigeria: a before-and-after study. Hum Resour Health. 2016;14(5):1-9. 